\title{
FAKTOR RESIKO PREEKLAMPSIA BERAT DI RUANG BERSALIN RUMAH SAKIT UMUM DAERAH DR. MOH. SOEWANDHI SURABAYA
}

\section{Risk factors for the development of severe preeclampsia in general hospital of Dr. Moh. Soewandhi Surabaya}

\author{
Latifiyan Nurnaningtiyas Aminoto ${ }^{1}$, Setyawati Soeharto Karyono. ${ }^{2}$, Dina Dewi S. L. I. ${ }^{3}$ \\ ${ }^{1}$ Program Magister Keperawatan Gawat Darurat Fakultas Kedokteran Universitas Brawijaya \\ ${ }^{2}$ Program Studi Pendidikan Dokter Fakultas Kedokteran Universitas Brawijaya \\ ${ }^{3}$ Program Magister Keperawatan Gawat Darurat Fakultas Kedokteran Universitas Brawijaya
}

\begin{abstract}
Severe preeclampsia is a problem that causes emergency, thus increasing morbidity and maternal mortality. There are several risk factors that influence the occurrence of severe preeclampsia. This study aimed to explore the risk factors associated with severe preeclampsia. The study design is cross sectional. sample 64 respondents, divided into 32 severe preeclampsia and mild preeclampsia 32 hospitals in the delivery room. dr. Moh. Soewandhi Surabaya. Logistic regression analysis of the test, it was found that obesity and stress is a risk factor that significantly affects the occurrence of severe preeclampsia.
\end{abstract}

Keywords : Risk factors, severe preeclampsia

\section{Pendahuluan}

Penyebab kematian maternal dan perinatal di negara maju dan berkembang adalah preeklampsia (Luealon, 2010). Menurut WHO, sekitar 585.000 ibu meninggal per tahun saat hamil atau bersalin, dimana $58,1 \%$ diantaranya dikarenakan oleh preeklampsia dan eklampsia (Manuaba, 2007). Menurut Ghulmiyyah (2012), Dari 63.000 wanita yang meninggal di Asia, Afrika, Amerika Latin dan Karibia, preeklampsia atau eklamsia berkontribusi sebesar $9 \%$ terhadap kematian wanita tiap tahunnya.

Preeklampsia juga merupakan penyebab utama kematian ibu di Jawa Timur. Jumlah Kematian Maternal sebesar 627 kasus dengan rincian $48,17 \%$ pada masa nifas, $22,49 \%$ kematian masa hamil, dan $29,35 \%$ waktu bersalin. Dimana penyebab kematian terbesar adalah 29,35\% perdarahan, $27,27 \%$ preeklampsia, $15,47 \%$ jantung, $6,06 \%$ infeksi dan $15,47 \%$ kasus lain. Dari persentase yang didapatkan, 60\% wanita preeklampsia terjadi di Surabaya (Rahaju, 2012). Berdasarkan laporan dari rekam medis, wanita yang datang untuk bersalin $\mathrm{Di}$ RSUD. dr. Moh. Soewandhi Surabaya dengan diagnosa preeklampsia dan eklampsia rata-rata sebanyak 45 wanita tiap bulannya pada tahun 2012. Sedangkan pada tahun 2013, jumlah tersebut mengalami peningkatan, dimana bulan Januari sebanyak 53 kunjungan dan februari 54 kunjungan.

Preeklampsia merupakan gangguan multisistem yang mengancam nyawa ibu dan janin (Steegers, 2010). Namun, 
mekanisme penyebab pre-eklampsia tetap tidak sepenuhnya dipahami. Para peneliti mengemukakan bahwa preeklamsia dikaitkan dengan kegagalan invasi trofoblas dari arteri spiralis ibu, yang menyebabkan peningkatan resistensi pembuluh darah dari arteri rahim dan penurunan aliran darah uteroplasenta (Sibai, 2005). Manifestasi klinis yang muncul yaitu hipertensi dan protein urin (Querini, 2007), edema, nyeri kepala, dan nyeri epigastrum (Jhaveri, 2009).

Usaha pemerintah yang sudah dilaksanakan dalam menurunkan angka kematian ibu meliputi pelayanan antenatalcare, deteksi dini untuk ibu dengan risiko komplikasi kehamilan, pertolongan persalinan oleh tenaga kesehatan, dan pelayanan nifas, yang mana dalam menjalankan program tersebut diperlukan koordinasi yang baik dengan bidan dan puskesmas setempat (Rahaju, 2011). Meskipun faktor risiko yang mempengaruhi terjadinya preeklampsia telah banyak diteliti di beberapa negara, hasilnya masih bertentangan. Beberapa penelitian telah dilakukan untuk menemukan faktor risiko preeklampsia pada populasi Asia. Terdapat perbedaan yang signifikan dalam prevalensi faktor risiko di Asia dibandingkan dengan etnis lainnya (Luealon, 2010) seperti halnya di Indonesia yang kaya akan suku bangsa. Terutama di Surabaya yang merupakan kota besar dengan berbagai suku pendatang, baik yang berasal dari dalam maupun luar negeri.

Tujuan dari penelitian ini untuk memprediksi faktor risiko yang mempengaruhi terjadinya preeklampsia berat yaitu paritas, riwayat hipertensi, riwayat diabetes, obesitas dan stress

\section{METODE}

Pada penelitian ini menggunakan desain cross sectional. Subyek dipilih secara consecutive sampling dengan kriteria inklusi ibu nifas yang bersedia menjadi responden dan merupakan pasien rujukan dan kriteria inklusi ibu dengan gemeli.

Desain ini menelaah hubungan antara faktor risiko yaitu paritas, riwayat hiperrtensi, riwayat diabetes, obesitas dan stress sebagai variabel bebas dengan variabel dependent preeklampsia berat. .

Sebanyak 64 sampel yang terbagi menjadi 32 preeklampsia berat dan 32 responden dengan preeklampsia ringan yang bertempat di ruang bersalin RSUD. dr. Moh. Soewandhi Surabaya. Pada bulan juni sampai juli 2013.

Analisis data meliputi analisis deskriptif dan uji hipotesis. Data kategorik dinyatakan dengan destribusi frekuensi. Uji hipotesis variabel dilakukan dengan menggunakan regresi logistik dengan nilai $p$ dianggap bermakna bila $<0,05$. Besar risiko dinyatakan dengan nilai odd ratio (OR), dinyatakan sebagai faktor risiko bila $O R>1$. Analisis multivariat dilakukan dengan analisis regresi logistik dengan metode enter.

\section{HASIL PENELITIAN}

Telah diperoleh data studi dokumentasi selama Juni sampai Juli 2013 didapatkan sampel penelitian 64 sampel terdiri dari 32 preeklampsia berat dan 32 preeklampsia ringan. Karakteristik subyek meliputi usia, 
pendidikan terakhir dan pekerjaan. Dari hasil penelitian didapatkan preeklampsia berat lebih banyak dialami pada ibu dengan usia 20-35 tahun yaitu 17 responden $(26,6 \%)$. Sama halnya dengan preeklampsia ringan, yang menunjukkan bahwa usia ibu dengan preeklampsia ringan, sebagian besar dialami oleh ibu dengan usia >35 dan 20-35 tahun masingmasing sebanyak 15 responden (23,4\%). Preeklampsia berat dan preeklampsia ringan lebih banyak dialami oleh ibu dengan pendidikan terakhir SD masing-masing 28 responden (43,8\%) dan 29 responden $(45,3)$. Preeklampsia beratb lebih banyak dialami oleh ibu rumah tangga yaitu sebesar 28 responden (43,8\%). Sama halnya dengan preeklampsia ringan, sebagian besar dialami oleh ibu rumah tangga, sebanyak 30 responden (46,9\%).

Kejadian preeklampsia berat lebih banyak dialami oleh ibu multipara yaitu 18 responden $(28,1 \%)$. Sama halnya dengan preeklampsia ringan, sebagian besar dialami oleh ibu multipara yaitu sebanyak 20 responden (31,2\%). Sebagian besar ibu dengan preeklampsia berat memiliki riwayat hipertensi yaitu 16 responden (25\%). Preeklampsia ringan lebih banyak dialami oleh ibu yang tidak memiliki riwayat penyakit hipertensi yaitu 23 responden (35,9\%).

Preeklampsia berat lebih banyak dialami oleh ibu dengan obesitas yaitu 22 responden (34,4\%). Sebaliknya dengan preeklampsia ringan, sebagian besar dialami oleh ibu normal (tidak obesitas), sebanyak 22 responden $(34,4 \%)$.
Preeklampsia berat lebih banyak dialami oleh ibu tanpa adanya riwayat diabetes yaitu 22 responden (34,4\%). Sama halnya dengan preeklampsia ringan, sebagian besar dialami oleh ibu tidak memiliki riwayat penyakit diabetes, sebanyak 28 responden $(43,8 \%)$. Preeklampsia berat lebih banyak dialami oleh ibu dengan tingkat stress tinggi yaitu 23 responden (35,9\%). Berbeda dengan preeklampsia ringan, sebagian besar dialami oleh ibu dengan tingkat stress tinggi, sebanyak 27 responden (42,2\%)

\section{Tabel 1}

\section{Hasil Analisis Bivariat Regresi Logistik Sederhana}

\begin{tabular}{lc}
\hline \multicolumn{1}{c}{ Variabel } & $P$ value \\
\hline Paritas & 0,611 \\
Riwayat hipertensi & 0,071 \\
Riwayat diabetes & 0,066 \\
Obesitas & 0,002 \\
Stress & 0,001 \\
\hline
\end{tabular}

Dari hasil analisa bivariat diatas, didapatkan hasil bahwa variabel yang memiliki nilai $p$ $<0,25$ adalah riwayat hipertensi $(0,071)$, riwayat diabetes $(0,066)$, obesitas $(0.002)$ dan stress $(0,001)$.

\section{Tabel 2}

\section{Hasil Analisis Multivariat Tahap Pertama}

\begin{tabular}{lcr}
\hline \multicolumn{1}{c}{ Variabel } & $\boldsymbol{P}$ & OR \\
\hline $\begin{array}{l}\text { Riwayat } \\
\text { hipertensi }\end{array}$ & 0.984 & 1.014 \\
$\begin{array}{l}\text { Riwayat } \\
\text { diabetes }\end{array}$ & 0.306 & 0.417 \\
$\begin{array}{l}\text { Obesitas } \\
\text { Stress }\end{array}$ & 0.018 & 4.799 \\
\hline
\end{tabular}


Tabel 3

Hasil Analisis Multivariat Tahap Kedua

\begin{tabular}{llc}
\hline \multicolumn{1}{c}{ Variabel } & $P$ value & OR \\
\hline Riwayat Diabetes & 0.303 & 0.418 \\
obesitas & 0.018 & 4.8 \\
Stress & 0.011 & 10.442 \\
\hline
\end{tabular}

Tabel 6

Hasil Analisis Multivariat Tahap Ketiga

\begin{tabular}{llr}
\hline \multicolumn{1}{c}{ Variabel } & $P$ value & OR \\
\hline obesitas & 0.025 & 4.186 \\
Stress & 0.001 & 12.598 \\
\hline
\end{tabular}

Berdasarkan hasil analisis multivariat diatas, dapat diketahui bahwa variabel yang memiliki hubungan dengan preeklampsia berat yaitu obesitas dan stress. Obesitas memiliki kekuatan hubungan $\mathrm{OR}=4.186$, artinya ibu yang mengalami obesitas akan memiliki kemungkinan 4.186 kali untuk terjadi preeklampsia berat jika dibandingkan dengan ibu yang normal. Stress memiliki kekuatan hubungan $(\mathrm{OR})=12.598$, artinya ibu yang mengalami stress tinggi memiliki kemungkinan terjadi preeklampsia berat sebesar 12.598 kali dibandingkan dengan ibu yang mengalami stress ringan

\section{Pembahasan}

\section{Hubungan Antara Paritas dengan Preeklampsia Berat}

Langelo (2012) menjelaskan bahwa paritas adalah jumlah anak yang diakdung dan dilahirkan oleh seorang wanita. Kehamilan pertama (primipara) memiliki resiko lebih tinggi untuk terjadi gangguan selama kehamilan dan nifas seperti preeklampsia berat. Menurut Saftlas (2003), wanita yang hamil akan memberikan efek perlindungan terhadap terjadinya preeklampsia berat pada kehamilan berikutnya, sedangkan pada wanita yang mengalami aborsi, memiliki perlindungan yang lemah. Hal ini dikaitkan dengan adanya mekanisme imunologi terhadap paparan antigen janin yang dimiliki ibu pada kehamilan pertama. Kekebalan tubuh didapatkan jika kehamilan berikutnya terjadi dengan ayah yang sama.

Berdasarkan dari analisis regresi logistik, dapat diketahui bahwa tidak ada hubungan antara paritas dengan kejadian preeklampsia berat. Wanita dengan multipara dan primipara memiliki kemungkinan untuk terjadi preeklampsia berat. Penelitian sebelumnya oleh Rozikhan (2007) menyatakan bahwa primipara merupakan faktor resiko yang memiliki peran pada kejadian preeklampsia berat. Dari data yang diperoleh dapat dibuktikan tidak ada keterkaitan antara kelahiran yang pernah dialami oleh seseorang dengan kejadian preeklampsia berat dan tidakterbukti adanya efek perlindungan yang didapatkan dari kehamilan sebelumnya.

Hasil penelitian yang didapat tidak sependapat dengan penelitian sebelumnya dikarenakan oleh adanya faktor resiko lain yang lebih dominan yaitu stress yang dialami oleh ibu dengan anak lebih dari satu dan bertambahnya berat badan ibu yang tidak terkontrol sehingga terjadi obesitas. Selain itu, wanita yang pernah mengandung dan melahirkan sebelumnya akan mengalami penurunan vaskularisasi. Desidua mengalami atropi akibat persalinan sebelumnya sehingga aliran darah ke plasenta tidak cukup, hal ini dapat menganggu fungsi yang akan berdampak 
pada gangguan pertumbuhan janin dan preeklampsia berat (Wiknjosastro, 2005).

\section{Hubungan Antara Riwayat Hipertensi}

\section{Dengan Preeklampsia berat}

Bagian dari otak yang mengontrol mekanisme konstriksi dan ralaksasi adalah medulla, disebut dengan pusat vasomotor. Dari pusat vasomotor ini, bermula jaras saraf simpatis, yang berlanjut ke bawah ke korda spinalis dan keluar dari kolumna medulla spinalis ganglia simpatis di toraks dan abdomen. Rangsangan pusat vasomotor dihantarkan dalam bentuk impuls yang bergerak ke bawah melalui system saraf simpatis ke ganglia simpatis. Pada titik ini, neuron preganglion melepaskan asetilkolin, yang akan merangsang serabut saraf pasca ganglion ke pembuluh darah, dimana dengan dilepaskannya norepineprin mengakibatkan konstriksi pembuluh darah (Brunner \& Suddarth, 2002 ).

Berdasarkan dari penelitian ini, didapatkan hasil bahwa tidak ada hubungan antara riwayat hipertensi dengan preeklampsia berat. Penelitian ini sama dengan penelitian sebelumnya oleh Rozikhan (2007), yang menyatakan bahwa tidak ada hubungan antara riwayat hipertensi dengan preeklampsia berat. Pendapat Lowe (2008) didukung oleh Agudelo (2000), menyatakan bahwa riwayat hipertensi merupakan faktor resiko yang berperan dalam kejadian preeklampsia berat.

Hasil penelitian yang diperoleh berbeda dengan penelitian sebelumnya, hal ini dikarenakan adanya faktor resiko lain yang lebih dominan. Selain itu, sebanyak $60 \%$ responden menyatakan bahwa meraka tidak mengetahui jika mengalami hipertensi sebelum hamil. Wanita yang memiliki riwayat hipertensi sebelum hamil tidak mengalami preeklampsia dikarenakan adanya kewaspadaan yang lebih tinggi dengan kondisi yang mereka alami, sehingga lebih bisa menjaga pola hidup agar kondisi tekanan darahnya stabil. Sedangkan wanita yang sebelumnya memiliki tekanan darah normal, kurang berhati-hati dalam menjaga kondisi tubuhnya hingga terjadi preeklampsia berat.

\section{Hubungan Antara Riwayat Diabetes dengan Preeklampsia Berat}

Sekresi insulin oleh kelenjar pankreas yang tidak adekuat menyebabkan terjadinya peningkatan kadar glukosa darah (De Laune, 2002). Hiperglikemia yang terjadi dalam jangka waktu yang lama dapat menimbulkan komplikasi yang bersifat akut maupun kronis (Holt et al, 2010). Salah satunya adalah nefropati berhubungan dengan adanya glomerulosklerosis yang mengakibatkan penurunan laju filtrasi glomerulus, proteinuria, hipertensi dan gagal ginjal (Reich et al, 2008). Mekanisme yang menjelaskan tentang hubungan diabetes melitus dengan penyakit jantung adalah adanya peningkatan tekanan darah dan efek dari metabolisme seperti hiperinsulinemia dan hiperglikemia (Gholap, 2011).

Berdasarkan dari hasil penelitian yang dilakukan, didapatkan hasil bahwa tidak adanya hubungan yang signifikan antara riwayat diabetes dengan kejadian preeklampsia berat. Hasil ini sama dengan penelitian yang sebelumnya pernah 
dilakukan oleh Rozikhan (2007) menyebutkan bahwa diabetes melitus tidak merupakan faktor risiko yang mempengaruhi terjadinya preeklampsia berat.

Data yang didapatkan berbeda dengan penelitian sebelumnya, karena wanita hamil dengan diabetes melitus akan lebih berrhati-hati dalam menjaga kondisi tubuhnya. Hal ini dikarenakan adanya pengalaman dan kemampuan mengontrol pola hidupnya agar kondisi tubuh $\mathrm{n}$ janinnya sehat. Wanita yang mengalami diabetes melitus bisa lebih rutin memeriksakan diri selama kehamilan, selain melihat kondisi janin juga melakukan pemeriksaan gula darah secara berkala, sehingga dapat menurunkan angka kejadian preeklampsia berat. Kondisi gula darah normal, lebih sering membuat wanita kurang waspada dan cenderung untuk tidak memeriksakan kadar gula darah mereka saat hamil.

\section{Hubungan antara obesitas dengan kejadian preeklampsia berat}

Obesitas dapat diartikan sebagai akumulasi lemak abnormal pada tubuh seseorang yang terjadi karena asupan energi yang melebihi pengeluaran kalori. Kondisi ini juga dipengaruhi oleh faktor genetik, metabolisme endokrin, faktor psikologis dan budaya. Wanita dengan obesitas memiliki risiko tinggi mengalami hipertensi dalam kehamilan (Oken, 2007). Obesitas dapat mengakibatkan komplikasi pada kehamilan dan persalinan seperti diabetes gestasional, hipertensi, preeklamsia berat, eklampsia, kematian janin (Beaten, 2001), kematian neonatal, dan cacat lahir (Watkins, 2003).
Berdasarkan dari hasil penelitian yang telah dilakukan, didapatkan hasil bahwa adanya hubungan yang signifikan antara obesitas yang dialami oleh ibu dengan preeklampsia berat. Obesitas yang dialami oleh ibu hamil merupakan faktor resiko yang sangat berperan dalam proses terjadinya preeklampsia. Dimana ibu dengan obesitas memiliki resiko 4 kali mengalami obesitas dibandingkan dengan ibu yang memiliki indeks masa tubuh normal. Penelitian ini sejalan dengan penelitian yang dilakukan oleh Clausen (2006) di Norwegia dan Asim (2010) di Kacachi Hospital Pakistan, menyatakan bahwa kelebihan berat badan pada wanita hamil dapat meningkatkan risiko hipertensi kehamilan yang akan berkembang menjadi preeklamsia berat sampai eklampsia. Kondisi ini akan meningkatkan berbagai komplikasi kehamilan yang dapat berakibat pada kondisi kegawatdaruratan ibu dan janin juga meningkatkan risiko kematian, baik saat maternal maupun prenatal.

Berdasarkan dari data hasil wawancara yang telah dilakukan dan catatan dari antenatal care, ibu yang mengalami obesitas sebagian besar sudah memiliki berat badan yang berlebih sebelum hamil. Kelebihan berat badan tersebut, dikarenakan kebiasaan mengkonsumsi makanan yang berlebih dan makan makanan ringan. Kebiasaan mengkonsumsi makanan yang tidak sehat seperti makanan siap saji seperti mie, nugget, dan sozzis. Responden lebih sering beli makanan jika dibandingkan dengan masak sendiri di rumah. Dimana makanan yang di jual bebas 
banyak mengandung bahan-bahan yang tidak aman buat kesehatan, baik itu pewarna, pengawet, pemutih dan pemanis buatan. Kebiasaan ini dikarenakan pasien mengalami mual, muntah, penurunan kondisi tubuh dan ketidakmampuan memakan makanan tertentu pada trimester pertama. Saat mendekati trimester ketiga, responden secara berlebihan mengkonsumsi makanan berlemak dan rendah serat.

\section{Hubungan antara tingkat stress dengan}

\section{kejadian preeklampsia berat}

Proses patofisiologi seperti disfungsi endotel, aktivasi respon inflammatori dan stres oksidatif dapat meningkatkan terjadinya preeklampsia (Roberts, 2003). Bukti terbaru menunjukkan bahwa sitokin ikut berpengaruh dalam stres oksidatif yang terkait dengan hipertensi dalam kehamilan (Ghabel, 2003). Pada mekanisme neuroendokrin manusia, stres berkorelasi positif dengan tingkat adrenocorticotropin hormone (ACTH) dan kortisol, sedangkan dukungan sosial yang tinggi berkorelasi negatif dengan ACTH dan kortisol (Fortner, 2009). Stress emosi yang terjadi menyebabkan peningkatan pelepasan corticotropic-releasing hormone (CRH) oleh hipothalamus, yang kemudian menyebabkan peningkatan kortisol. Efek kortisol adalah mempersiapkan tubuh untuk berespons terhadap semua stresor dengan meningkatkan respons simpatis, termasuk respons yang ditujukan untuk meningkatkan curah jantung dan mempertahankan tekanan darah. Pada wanita dengan preeklamsia/eklamsia, tidak terjadi penurunan sensitivitas terhadap vasopeptida-vasopeptida tersebut, sehingga peningkatan besar volume darah langsung meningkatkan curah jantung dan tekanan darah.

Berdasarkan dari hasil wawancara yang telah dilakukan, di dapatkan keterangan bahwa semua responden mengakui dan mengerti bahwa mengalami stress, namun tidak bisa mengontrolnya sendiri. Semua responden mengatakan bahwa kondisi hipertensi yang dialaminya karena stress yang dirasakannya saat hamil dan menuju persalinan. Penyebab stress yang berasal dari ibu itu sendiri dipengaruhi oleh kecerdasan emosional dan kecerdasan spiritual dari masing-masing individu. Sebagian ibu menyatakan bahwa keterlambatan persalinan yang dialami oleh ibu tersebut meningkatkan stress yang dirasakan oleh ibu, ditambah juga dengan kekhawatiran akan kondisi janin saat terlalu lama berada di dalam kandungan.

Selain kondisi ibu itu sendiri, lingkungan juga ikut menentukan peningkatan stress yang dirasakan oleh ibu hamil. Seperti kebutuhan hidup yang semakin meningkat dimana tidak diikuti dengan adanya peningkatan penghasilan dari suami maupun diri sendiri. Berdasarkan data juga bisa di ketahui bahwa tingkat ketergantungan ekonomi yang tinggi pada penghasilan suami, dimana $90 \%$ responden merupakan ibu rumah tangga. Kondisi ekonomi ini juga merupakan penyebab kecemasan dari responden saat hamil dengan anak yang telah dimilikinya lebih dari satu. 
Sebagian besar responden (40\%) masih tinggal serumah dengan mertua atau orang tua, dimana dalam satu rumah ada lebih dari satu kepala keluarga yang memungkinkan terjadi peningkatan stress saat terjadi ketidakcocokan dengan anggota keluarga lain yang beragam. Selain konflik dengan mertua, orang tua, dan saudara lainnya, responden juga ada yang bermasalah dengan suami mereka sendiri. Responden yang memiliki suami temperamen cenderung akan mengakibatkan peningkatan stress. Responden mengaku hampir setiap hari bertengkar dengan suami mereka karena ketidakcocokan dan tidak terpenuhinya harapan.

Semua responden tidak bisa tidur saat menunggu persalinan dan bisa tidur dengan nyenyak setelah terjadi persalinan. Hal ini dikarenakan program dari rumah sakit untuk membatasi jam besuk dan jumlah keluarga yang bisa bertemu dengan responden selama waktu perawatan. Responden juga mengaku bisa tidur dengan nyenyak dan terasa lebih tenang saat bayi mereka sudah dilahirkan dengan selamat. Mereka mengaku merasakan rasa ngantuk dan kelelahan setelah melahirkan bayinya.

\section{Peran Perawat}

Weidenbach menjelaskan bahwa prinsip keperawatan yang bisa dilakukan pada pasien dengan kegawatdaruratan maternitas (preeklampsia berat) yaitu nursing art yang dalam aplikasinya menggunakan pedoman need for help. Masalah utama yang muncul pada responden adalah obesitas dan stress.
Masalah keperawatan yang muncul pada responden adalah nutrisi lebih dari kebutuhan tubuh dan mekanisme koping.

Menurut Wiedenbach, inti dari pemberian asuhan keperawatan adalah pengalaman individu. Kondisi individu sebelum terjadinya penyakit merupakan acuan utama dalam pemberian asuhan keperawatan. Hal ini menjadi pedoman bagi perawat untuk mengatasi masalah pasien dengan mengidentifikasi faktor resiko yang mempengaruhi terrjadinya preeklampsia berat. Faktor resiko ditentukan dengan mmengidentifikasi, pencatatan dan memvalidasi. Setelah didapatkan hasilnya, maka bisa dipublikasikan dengan semua tenaga medis supaya dapat berkolaborasi dalam mengatasi masalah responden. Berdasarkan hasil penelitian, didapatkan bahwa faktor resiko yang mempengaruhi terjadinya preeklampsia adalah obesitas dan stress (Parker, 2010)

Berdasarkan teori keperawatan Wiedenbach, tindakan keperawatan yang bisa diberikan pada pasien dengan memberikan motivasi dan memfasilitasi individu untuk berupaya mengatasi masalahnya. Saat seseorang mengalami stress, diperlukan adanya kemampuan dalam diri sendiri untuk mengatasinya. Kecerdasan emosional dan spiritual dalam diri seseorang bisa dioptimalkan untuk menurunkan stress yang dialami meraka, dengan demikian diperlukan kemampuan perawat "nursing art" dalam memberikan asuhan keperawatan. Prinsip need for help diterapkan dalam memberikan asuhan keperawatan pada preeklampsia berat, 
dimana pasien membutuhkan bantuan perawat dalam mengatasi masalahnya (Parker, 2010).

\section{KESIMPULAN}

Penelitian ini dapat disimpulkan bahwa faktor resiko yang dominan mempengaruhi terjadinya preeklampsia berat yaitu obesitas dan stress yang dialami oleh responden. Ibu dengan obesitas memiliki resiko 4 kali untuk terjadi preeklampsia berat jika dibandingkan pada ibu yang tidak obesitas dan keadaa stress tinggi yang dialami menyumbangkan 12 kali kemungkinan untuk terjadi preeclampsia berat. Variabel paritas, riwayat hipertensi dan riwayat diabetes tidak merupakan faktor resiko yang mempengaruhi terjadinya preeklampsia berat.

\section{DAFTAR PUSTAKA}

Agudelo A., Belizan J. (2001). Risk Factors for Pre-Eclampsia in Large Cohort of Latin American and Caribbean Women, BJOG. 107 (1): 75-83.

Beaten JM, Bukusi EA, Lambe M. (2001). Pregnancy complications and utcomes in overweight and obese nulliparous women. Am J Public Health, 91, 436-40

De laune, C.S., Ladner, K.P. (2002). Fundamentals of nursing. Standard \& practice. Second Edition. New York : D elmar Thomson Learning. Inc.

Clausen T, Oyen N, Henriksen T. (2006). Pregnancy complications by overweight And residential area:a prospective study of an urban Norwegian cohort. Acta Obstet Gynecol Scand 2006;85:526-33.

Fortner Shannon. (2009). Modifable Risk Factors for Hypertensive Disorders of Pregnancy Among Latina Women. Public Health Biostatistics and Epidemiology . University of Massachusets Amherst.

Ghabel M, Mohamadalizade S, Mahdavi R. (2003). Comparing the Condition of
Nutrition in Pre-eclampsia and Normotensive Pregnant Women.

Journal of Mashhad School of Nursing \& Midwifery, 5, 1-8.

Ghulmiyyah L, Sibai B. (2012). Maternal mortality from preeclampsia/eclampsia. Sem Perinatol, 36,56-59.

Jhaveri K. D. Aelion A. Wanchoo R. (2009). Pre-eclampsia presenting as hyponatremia: an uncommon presentation of pre-eclampsia in a twin pregnancy-a case report and review of the literature. Clinical Nephrology, 72, 6 (492-496).

Langelo W. (2012). Faktor Resiko Kejadian Preeklampsia Di RSKD lbu dan Anak Siti Fatimah Makassar. Makassar: Universitas Hasanuddin.

Lowe S. A., Brown M. A., Dekker G., Gatt S., McLintock C., McMahon L,et all. (2008). Guidelines For The Management Of Hypertensive disorders Of Pregnancy 2008. Society Of Obstetric Medicine of Australia and new Zealand.

Luealon P., Phupong V . (2010). Risk Factors of Preeclampsia in Thai Women. J. Med Assoc Thai, 93, 6.

Oken E, Ning Y, Rifas-Shiman SL, RichEdwards JW, Olsen SF, et al. (2007).

Diet during pregnancy and risk of preeclampsia or gestational hypertension. Ann Epidemiol 17: 663668.

Parker M. E., Smith, M. C. (2010). Nursing theories and nursing practice. Philadelphia :F. A. Davis Company

Querini. (2007). Signals of cell death and tissue turnover during physiological pregnancy, pre-eclampsia, and autoimmunity. , 40(4), 290-294

Rahaju Budi. (2012). Profil Kesehatan Provinsi Jawa Timur Tahun 2011. Surabaya: Dinas Kesehatan Provinsi Jawa Timur.

Reich, H.N. et al. (2008). Decreased glomer ular and tubular expression of ACE2 in patients with type 2 diabetes and kidne y disease. Kidney International, 74: 16101616.

Roberts JM, Pearson G, Cutler J, Lindheimer M (2003). Summary of the NHLBI Working Group on Research on Hypertension During Pregnancy. Hypertension, 41, 437-445. 